Prepared in cooperation with the Iroquois River Conservancy District

\title{
Regression Models for Estimating Sediment and Nutrient Concentrations and Loads at the Iroquois River near Foresman, Indiana, March 2015 through July 2018
}

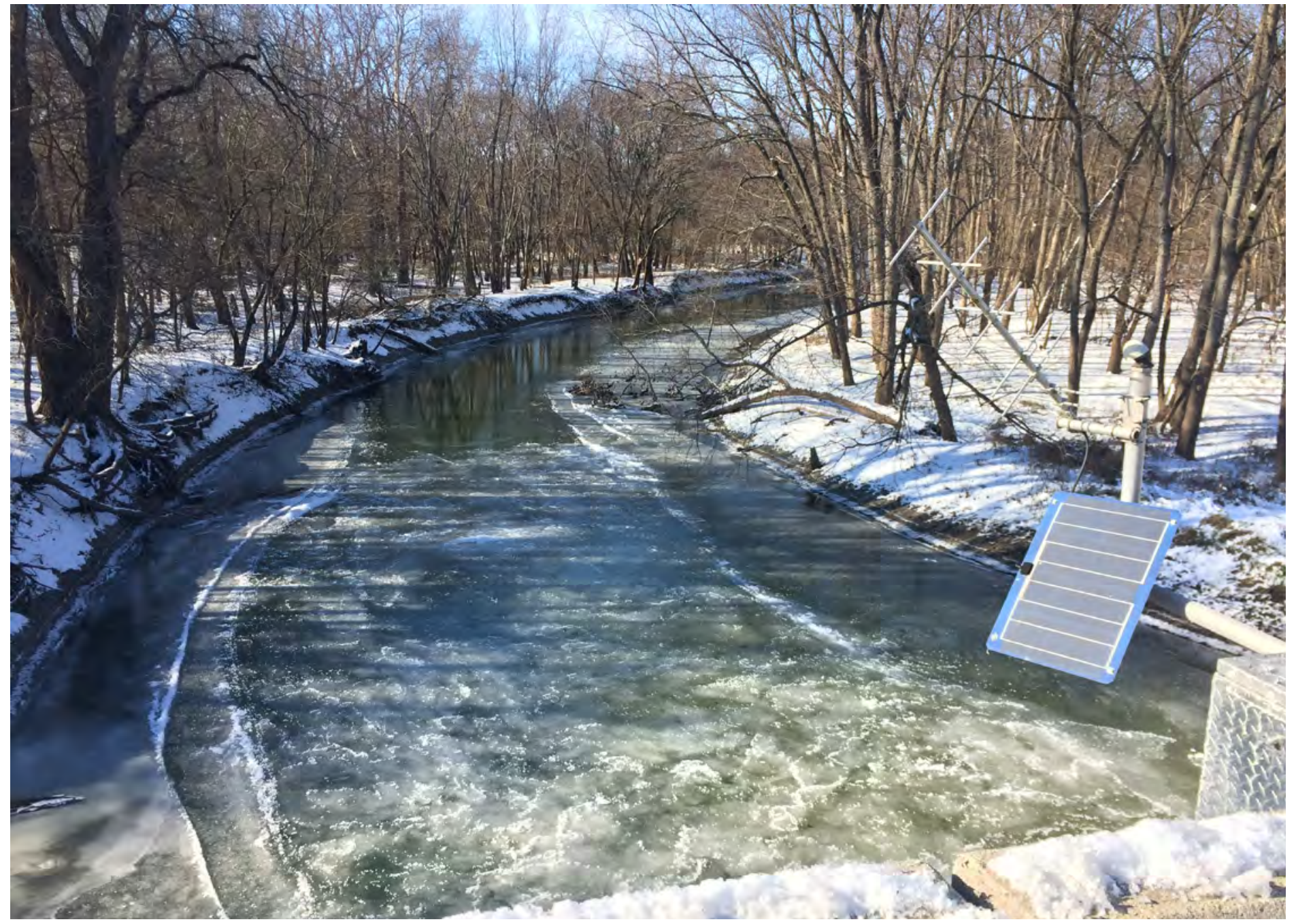

Scientific Investigations Report 2019-5087 
Cover. Photograph showing the ice-covered Iroquois River at the continuous water-quality monitoring station Iroquois River near Foresman, Indiana (U.S. Geological Survey station 05524500). Photograph taken on December 15, 2016, by Zachary Razor, U.S. Geological Survey.

Back cover. Photograph showing the water-quality monitor housing during low-flow conditions at the continuous water-quality monitoring station Iroquois River near Foresman, Indiana (U.S. Geological Survey station 05524500). Photograph taken on March 20, 2015, by Bradley Reinking, U.S. Geological Survey. 


\section{Regression Models for Estimating \\ Sediment and Nutrient Concentrations and Loads at the Iroquois River near Foresman, Indiana, March 2015 through July 2018}

By Timothy R. Lathrop, Aubrey R. Bunch, Myles S. Downhour, and Daniel M. Perkins

Prepared in cooperation with the Iroquois River Conservancy District

Scientific Investigations Report 2019-5087 


\title{
U.S. Department of the Interior DAVID BERNHARDT, Secretary
}

\author{
U.S. Geological Survey \\ James F. Reilly II, Director
}

U.S. Geological Survey, Reston, Virginia: 2019

For more information on the USGS - the Federal source for science about the Earth, its natural and living resources, natural hazards, and the environment-visit https://www.usgs.gov or call 1-888-ASK-USGS.

For an overview of USGS information products, including maps, imagery, and publications, visit https://store.usgs.gov.

Any use of trade, firm, or product names is for descriptive purposes only and does not imply endorsement by the U.S. Government.

Although this information product, for the most part, is in the public domain, it also may contain copyrighted materials as noted in the text. Permission to reproduce copyrighted items must be secured from the copyright owner.

Suggested citation:

Lathrop, T.R., Bunch, A.R., Downhour, M.S., and Perkins, D.M., 2019, Regression models for estimating sediment and nutrient concentrations and loads at the Iroquois River near Foresman, Indiana, March 2015 through July 2018: U.S. Geological Survey Scientific Investigation Report 2019-5087, 14 p., https://doi.org/10.3133/sir20195087.

ISSN 2328-0328 (online) 


\section{Contents}

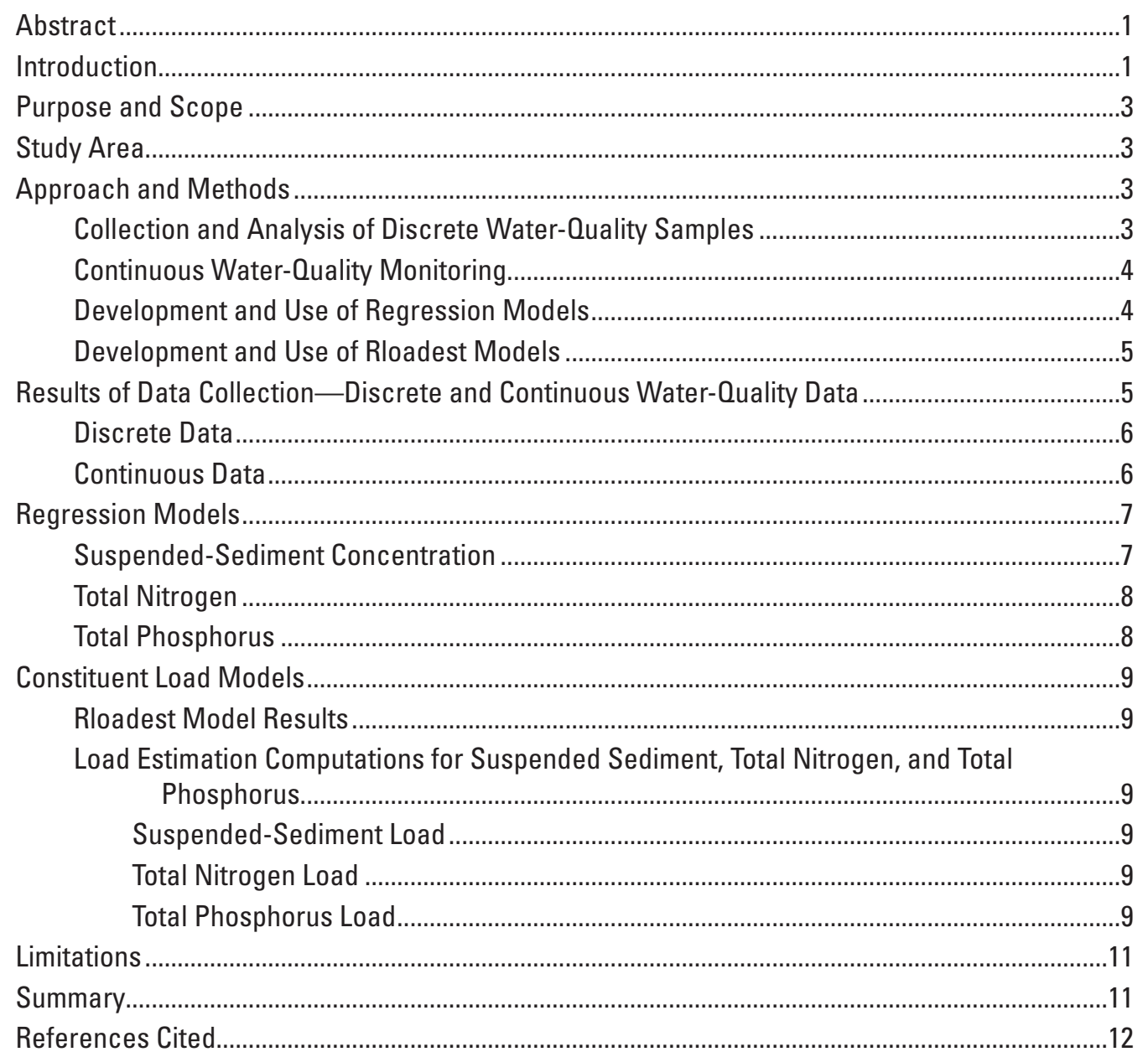




\section{Figures}

1. Map showing the Iroquois River Basin and the location of the Iroquois River near Foresman, Indiana, continuous water-quality monitoring station ...

2. Graphs showing discharge and estimated monthly loads at the Iroquois River near Foresman, Indiana, continuous water-quality monitoring station, for April 2015 through July 2018 computed from combined regression and rloadest models with monthly 90 -percent prediction intervals

\section{Tables}

1. Water-quality constituent data from discrete samples collected by the U.S. Geological Survey at the Iroquois River near Foresman, Indiana, continuous water-quality monitoring station, April 2015 through July 2018, and used in model development.

2. Range of in situ, continuous streamflow and water-quality values measured the Iroquois River near Foresman, Indiana, continuous water-quality monitoring station, March 2015 through July 2018

3. Regression models for selected water-quality constituents at the Iroquois River near Foresman, Indiana, continuous water-quality monitoring station, March 2015 through July 2018

4. Estimated annual loads and yields of suspended sediment, total nitrogen, and total phosphorus computed from daily loads of regression and rloadest models for the Iroquois River near Foresman, Indiana, continuous water-quality monitoring station, from April 2015 through July 2018 


\section{Conversion Factors}

U.S. customary units to International System of Units

\begin{tabular}{|c|c|c|}
\hline Multiply & By & To obtain \\
\hline \multicolumn{3}{|c|}{ Length } \\
\hline foot $(\mathrm{ft})$ & 0.3048 & meter $(\mathrm{m})$ \\
\hline mile (mi) & 1.609 & kilometer $(\mathrm{km})$ \\
\hline \multicolumn{3}{|c|}{ Area } \\
\hline acre & 0.004047 & square kilometer $\left(\mathrm{km}^{2}\right)$ \\
\hline square mile $\left(\mathrm{mi}^{2}\right)$ & 2.590 & square kilometer $\left(\mathrm{km}^{2}\right)$ \\
\hline \multicolumn{3}{|c|}{ Flow rate } \\
\hline cubic foot per second $\left(\mathrm{ft}^{3} / \mathrm{s}\right)$ & 0.02832 & cubic meter per second $\left(\mathrm{m}^{3} / \mathrm{s}\right)$ \\
\hline \multicolumn{3}{|c|}{ Mass } \\
\hline ton, short $(2,000 \mathrm{lb})$ & 0.9072 & metric ton $(\mathrm{t})$ \\
\hline \multicolumn{3}{|c|}{ Hydraulic gradient } \\
\hline foot per mile (ft/mi) & 0.1894 & meter per kilometer $(\mathrm{m} / \mathrm{km})$ \\
\hline
\end{tabular}

\section{Datum}

Horizontal coordinate information is referenced to the North American Datum of 1983 (NAD 83).

\section{Supplemental Information}

Specific conductance is given in microsiemens per centimeter at 25 degrees Celsius $(\mu \mathrm{S} / \mathrm{cm}$ at $\left.25^{\circ} \mathrm{C}\right)$.

Concentrations of chemical constituents in water are given as milligrams per liter (mg/L).

Turbidity units are given in formazin nephelometric units (FNU). 


\section{Abbreviations}

$\begin{array}{ll}B p & \text { load bias percentage } \\ E & \text { Nash Sutcliffe efficiency index } \\ p & \text { probability } \\ P L R & \text { partial load ratio } \\ \text { PRESS } & \text { predicted residual error sum of squares } \\ Q & \text { streamflow } \\ R^{2} & \text { coefficient of determination } \\ \text { SSL } & \text { suspended-sediment load } \\ \text { t/mi2/yr } & \text { tons per square mile per year } \\ \text { TNL } & \text { total nitrogen load } \\ \text { TPL } & \text { total phosphorus load } \\ \text { USGS } & \text { U.S. Geological Survey }\end{array}$




\title{
Regression Models for Estimating Sediment and Nutrient Concentrations and Loads at the Iroquois River near Foresman, Indiana, March 2015 through July 2018
}

\author{
By Timothy R. Lathrop, ${ }^{1}$ Aubrey R. Bunch, ${ }^{1}$ Myles S. Downhour, and Daniel M. Perkins ${ }^{2}$
}

\section{Abstract}

In 2015, the U.S. Geological Survey, in cooperation with the Iroquois River Conservancy District, deployed continuous water-quality monitors and began collecting representative discrete water-quality samples at the Iroquois River near Foresman, Indiana, streamflow-gaging station (U.S. Geological Survey station 05524500). By relating continuously monitored water-quality data and discrete water-quality samples collected from April 2015 through July 2018, regression models that estimate concentrations of suspended sediment, total nitrogen, and total phosphorus were developed. Developed regression models indicated a strong correlation between turbidity and streamflow with suspended-sediment concentration (adjusted coefficient of determination equals 0.84 , predicted residual error sum of squares equals 0.493 ), nitrate plus nitrite and streamflow with total nitrogen (adjusted coefficient of determination equals 0.99 , predicted residual error sum of squares equals 0.0202), and specific conductance and turbidity with total phosphorus (adjusted coefficient of determination equals 0.84 , predicted residual error sum of squares equals 0.0935 ).

Daily loads of suspended sediment, total nitrogen, and total phosphorus were computed as the product of daily mean regression model concentrations and daily mean streamflow. During periods when regression model concentrations could not be computed, rloadest models, the R programming language version of the LOADEST FORTRAN program, were used to compute daily loads of each constituent. For 2016 and 2017 , the estimated annual suspended-sediment loads were 25,000 and 32,100 tons; estimated total nitrogen loads were 4,260 and 5,780 tons; and estimated total phosphorus loads were 104 and 128 tons, respectively.

\section{Introduction}

The Iroquois River, the largest tributary of the Kankakee River (not shown), drains 660 square miles $\left(\mathrm{mi}^{2}\right)$ of area in northwestern Indiana (fig. 1; U.S. Geological Survey, 2016a). Historically, the upper reaches of the Iroquois River watershed consisted of marshland, whereas the lower area was primarily composed of prairies (Bhowmik and others, 1980; Ivens and others, 1981; Jonas and Little, 2010). Extensive anthropogenic changes to the river including ditching and channelization began in the late 19th century, altering the basin for improved agricultural use (Bhowmik and others, 1980; Ivens and others, 1981).

The Iroquois River Conservancy District is an Indiana drainage board, composed of members from Newton and Jasper Counties, that is responsible for improving farm drainage; reducing hazards to public health and safety caused by excessive stormwater runoff; enhancing economic objectives; and protecting, conserving, and promoting the orderly development of land and water resources within the counties (D. Blaney, oral commun., 2019). In 2015, the U.S. Geological Survey (USGS), in cooperation with the Iroquois River Conservancy District, deployed continuous water-quality monitors and began collecting representative discrete water-quality samples at the Iroquois River near Foresman, Indiana, continuous water-quality monitoring station (USGS station 05524500; hereafter referred to as "Iroquois River near Foresman, Ind."), which has a drainage area of $449 \mathrm{mi}^{2}$. By combining in situ continuous data with discrete water-quality samples using linear regression, this 4-year study estimated concentrations and loads of suspended sediment, total nitrogen, and total phosphorus.

\footnotetext{
${ }^{1}$ U.S. Geological Survey.

${ }^{2}$ Jasper County Soil and Water Conservation District.
} 


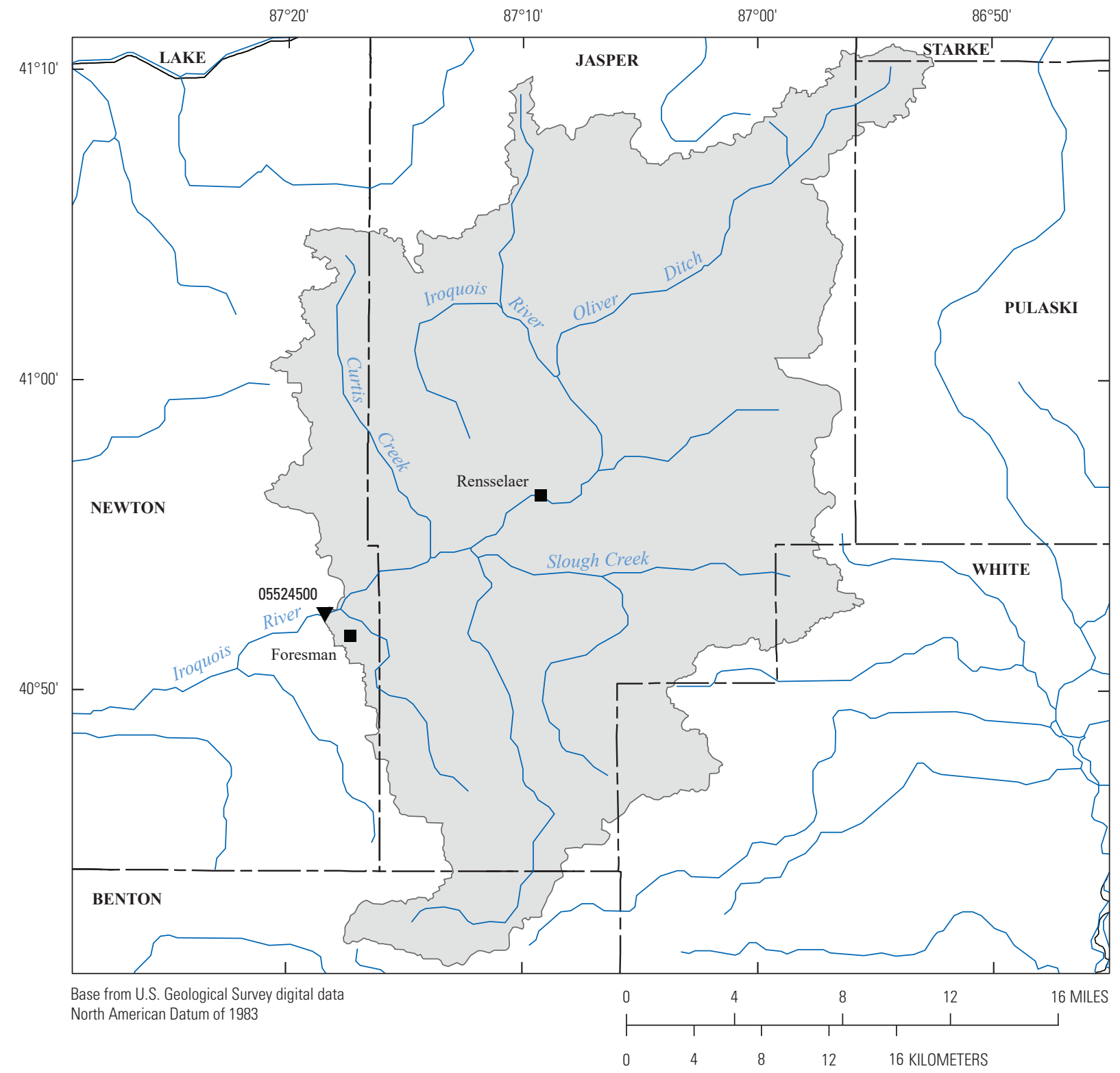

EXPLANATION

Iroquois River near Foresman, Indiana, drainage basin

$05524500 \quad \begin{gathered}\text { Iroquois River near Foresman, Indiana, } \\ \text { continuous water-quality monitoring } \\ \text { station and identifier }\end{gathered}$

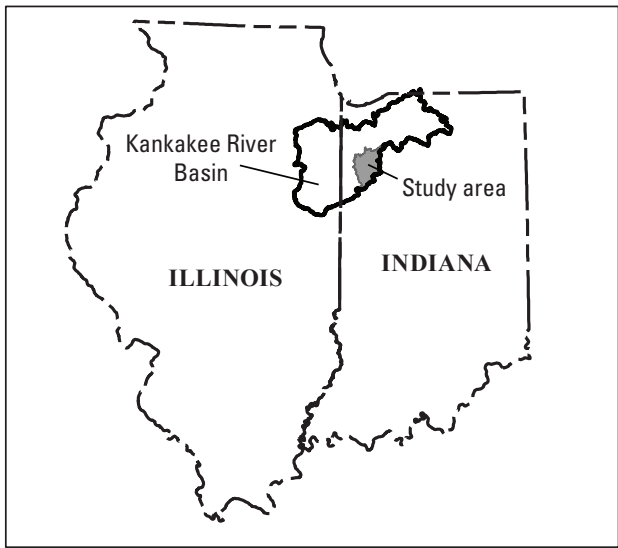

Figure 1. The Iroquois River Basin and the location of the Iroquois River near Foresman, Indiana, continuous waterquality monitoring station (U.S. Geological Survey station 05524500). 


\section{Purpose and Scope}

The purpose of this report is to document the application of models computed from regression analysis for suspended sediment, total nitrogen, and total phosphorus at the Iroquois River near Foresman, Ind., using data collected from March 2015 through July 2018. Developed regression models statistically relate in situ, continuous water-quality data with analytical results from periodically collected discrete samples throughout the range of hydrologic and seasonal conditions. The models summarized in this report can be used to estimate suspended-sediment, total nitrogen, and total phosphorus concentrations and loads at the Iroquois River near Foresman, Ind., with ongoing model validation. The baseline dataset and developed models will provide the Iroquois River Conservancy District, other agencies, and the public with information and tools to quantify constituent transport and assess the effects from environmental factors, changing land use practices, and management decisions on the Iroquois River.

\section{Study Area}

The Iroquois River in Indiana has a drainage area of $660 \mathrm{mi}^{2}$ (U.S. Geological Survey, 2016a). The Iroquois River, from its source north of Rensselaer, Ind., flows in a southwestwardly direction to Illinois (fig. 1). Major tributaries of the Iroquois River in Indiana include Slough Creek $\left(145 \mathrm{mi}^{2}\right)$, Oliver Ditch ( $\left.82 \mathrm{mi}^{2}\right)$, and Curtis Creek (39 mi ; fig. 1). The average slope of the river within Indiana is 1.28 feet per mile (ft/mi; U.S. Geological Survey, 2016a).

The Iroquois River lies within the Central Till Plain physiographic region of Indiana (not shown; Gray, 2001). The surficial geology consists of a variety of unconsolidated deposits, including dune sand in the north, lacustrine and outwash in the central reaches, and till (as end/ground moraines) in the south, all of which were deposited in the Wisconsin glaciation (Ivens and others, 1981). Unconsolidated sediment thickness in the Iroquois River Basin ranges from 0 feet, near Rensselaer, to as thick as 200 feet in some areas north of the river (Gray, 2001).

Land use of the basin is composed of row-crop agriculture ( 84 percent), urban areas (6 percent), forested land (6 percent), and minimal isolated riverine wetlands. Row-crop agriculture in the basin is dominated by corn and soybeans, with few wheat and hay fields. Rensselaer is the largest urban area within the study area and most of the city's combined sewage overflows discharge directly into the river (U.S. Geological Survey, 2016a; Indiana Geological Survey, 2019).

Historically, the upper reaches of the Iroquois River watershed consisted of marshland, a 400,000-acre wetland called the Grand Marsh (Bhowmik and others, 1980; Ivens and others, 1981; Jonas and Little, 2010). The lower reaches of the watershed were characterized by grass prairies, isolated wooded areas, and low-gradient silty streams and creeks (Homoya and others, 1985; Jarvis, 2001). As early as the 1860s, marshland and riverways in northwestern Indiana began to be converted for agricultural use (Bhowmik and others, 1980). Sections of the Iroquois River were channelized, and lateral ditches were constructed, leading to increased river slope and velocity. As a result, riparian corridors were drained, decreasing localized flooding and improving near-river areas for agricultural use. Downstream from Indiana, much of the riverway remained in its natural form, leading to increased flooding and sedimentation of downstream nonchannelized, low-gradient reaches (Bhowmik and others, 1980; Ivens and others, 1981).

The Iroquois River is a substantial contributor of sediment and nutrients within the Kankakee River Basin (Demissie and others, 1983; Phipps and others, 1995; Holmes, 1997; Terrio and Nazimek, 1997; Sullivan, 2000; Smith and others, 2003; Risch and others, 2014). The Iroquois River, which drains 41 percent of the Kankakee River Basin, strongly affects the water quality of the Kankakee River during highflow conditions (Demissie and others, 1983; U.S. Geological Survey, 2016a). Within the upper Iroquois River watershed, management activities are being completed to decrease the frequency of high-flow events; improve wildlife habitat and recreation; and reduce high concentrations of nutrients, sediment, and Escherichia coli (Perkins, 2013).

In 1948, the USGS streamflow-gaging station Iroquois River near Foresman, Ind., was installed to measure streamflow. In 1955, the streamflow-gaging station was relocated 2 miles (mi) downstream, allowing for installation of newer technology. The drainage area of the Iroquois River near Foresman, Ind., streamflow-gaging station (05524500) is $449 \mathrm{mi}^{2}$ (U.S. Geological Survey, 2016a). This streamflowgaging station, which is about 18 mi upstream from the Indiana-Illinois border, is the most downstream USGS streamflowgaging station on the Iroquois River within Indiana. All data analyzed for this report were collected at the current (2019) streamflow-gaging station.

\section{Approach and Methods}

The development of regression models for suspended sediment, total nitrogen, and total phosphorus relied on the collection of representative discrete water-quality samples and the operation of in situ continuous monitors throughout the range of water-quality conditions.

\section{Collection and Analysis of Discrete Water- Quality Samples}

Discrete water-quality samples used in the development of regression models were collected by USGS field crews from April 7, 2015, through July 19, 2018. Initially, waterquality samples were collected on a fixed schedule of every 2 weeks from April through October and monthly during cooler months. In late 2016 through the end of the project, the 
sampling design was altered to target high-flow events and better document the range of constituents transported by the river.

Discrete water-quality samples were collected using nationally consistent field protocols as outlined in the USGS National Field Manual for the Collection of Water-Quality Data (U.S. Geological Survey, variously dated). Flowweighted mean concentration samples were collected from the downstream side of the bridge at the monitoring site using the USGS equal-width-increment method to represent the cross section and water column of the river. During each site visit, the cross section of the stream was sampled twice to provide complete samples for analysis of (1) nutrients and (2) suspended sediment. Using a churn splitter, the nutrient sample was subset into two containers for evaluation of unfiltered, whole water constituents and filtered constituents smaller than 0.45 micron. Whole water nutrient samples were preserved with 1 milliliter of sulfuric acid. After preservation, nutrient samples were chilled and shipped for analysis. Each nutrient sample was analyzed by the USGS National Water Quality Laboratory for total and dissolved nitrogen and phosphorus using published methods (Fishman, 1993; O'Dell, 1993; Patton and Kryskalla, 2003, 2011). The volume collected for the suspended-sediment sample was analyzed for concentration and sand/fines composition at the USGS Kentucky Sediment Laboratory using analytical methods described by Guy (1969). Results from these two laboratories were reviewed and quality assured by USGS personnel and stored in the USGS National Water Information System (U.S. Geological Survey, 2016b).

\section{Continuous Water-Quality Monitoring}

The Iroquois River near Foresman, Ind., streamflowgaging station has operated continuously since 1949. In March 2015, two water-quality monitors that together continuously measure water temperature, specific conductance, $\mathrm{pH}$, dissolved oxygen, turbidity, and nitrate plus nitrite concentration were installed. A YSI 6600 5-parameter water-quality sonde and a Satlantic Submersible Ultraviolet Nitrate Analyzer V2-5 nitrate monitor are housed in flow-through polyvinyl chloride (commonly known as PVC) pipes affixed to the downstream side of the bridge pier and situated in well-mixed, flowing water. The 5-parameter water-quality sonde and nitrate monitor were deployed year-round, measuring water quality every 15 minutes. All continuous measurements are stored on a datacollection platform at the site and are transmitted hourly by the Geostationary Operational Environmental Satellite for storage, review, and archival in the publicly available USGS National Water Information System (U.S. Geological Survey, 2016b).

Continuous water-quality monitors are operated following documented USGS protocols (Wagner and others, 2006; Pellerin and others, 2013). Each monitor is cleaned and checked for calibration drift, which is an electronic shift in instrument reading of a known standard, about biweekly from April through October and monthly from November through
March when biofouling, which is fouling by underwater organisms such as algae, is not as prominent. During site visits, the USGS personnel evaluate and record the magnitude of any fouling and calibration drift. The field inspection information is used later to correct for drift and fouling. Data that are rated worse than poor and exceed parameter thresholds cannot be corrected and are removed from the record (Wagner and others, 2006; Pellerin and others, 2013).

Infrequently, equipment malfunctions, excessive fouling, and high instrument drift resulted in periods of missing continuous data. For the study period, daily mean values of continuous turbidity, specific conductance, nitrate plus nitrite, and streamflow were approved 95.7, 97.3, 93.7, and 99.9 percent of the time, respectively.

\section{Development and Use of Regression Models}

Regression models are based on concurrent measurements of discrete and continuous water-quality data collected from April 7, 2015, through July 19, 2018, and archived in USGS data releases (Lathrop, 2019a, b). Discrete samples were collected throughout the range of hydrologic and seasonal conditions. Continuous data that closely correspond to the date and time of each discrete sample were selected.

Potential outliers of each model dataset were identified by inspecting studentized residuals; a studentized residual is the quotient resulting from the division of a residual by an estimate of its standard deviation. Quotients outside of the range of 3 to -3 are considered potential outliers and receive further evaluation. A discrete sample of suspended-sediment concentration (July 19, 2018) exceeded the studentized residual threshold and received further review. The sample result collected during low turbidity conditions ( 3.7 formazin nephelometric units) had a concentration (30 milligrams per liter $[\mathrm{mg} / \mathrm{L}]$ ) larger than 72 percent of all other samples during the study period. This sample might have been negatively affected by error during sampling and was not used in model development.

A discrete sample of total nitrogen (March 28, 2016) exceeded the studentized residual threshold and received further review. The discrete sample, analyzed for nitrogen species, had a total nitrogen concentration $(6.01 \mathrm{mg} / \mathrm{L})$ smaller than the nitrate plus nitrite concentration $(7.19 \mathrm{mg} / \mathrm{L})$ as determined from analysis by the laboratory. Nitrate plus nitrite concentration represents only a part of the total nitrogen species and should therefore be less than or equal to the total nitrogen concentration. Analyses for total nitrogen and nitrate plus nitrite were verified by the analyzing laboratory. The continuous, in situ value of nitrate plus nitrite measured closest to the time the discrete sample was collected was $7.09 \mathrm{mg} / \mathrm{L}$. The real value of total nitrogen was likely larger than $7.19 \mathrm{mg} / \mathrm{L}$. The total nitrogen sample for March 28, 2016, was not used in model development.

Regression models were developed following USGS protocols and methods (Helsel and Hirsch, 2002; Rasmussen 
and others, 2009). Each regression model relates laboratoryanalyzed discrete water-quality sample data with in situ, continuous water-quality monitor measurements. Ordinary least-squares regression was used to evaluate and determine the optimal continuous water-quality parameter(s) (explanatory variables) to be used as surrogates for each of the discrete constituents - suspended sediment, total nitrogen, and total phosphorus (response variables). Statistical models for each possible combination of explanatory and response variables were produced using stepwise regression in the R statistical package version 3.1.2 (R Core Team, 2018) for suspended sediment and R statistical package version 3.5.2 (R Core Team, 2018). A variety of model statistics and diagnostics were used to determine the best predictors of each modeled constituent including tests of significance, standard error, adjusted coefficient of determination $\left(R^{2}\right)$, and the predicted residual error sum of squares (PRESS) statistic. The PRESS statistic provides a measure of the cross-validation summary of the model fit to a sample of observations not used to estimate the model. In general, the smaller the PRESS statistic, the better the model's predictive ability (Helsel and Hirsch, 2002).

To improve potential models, explanatory and response variables were evaluated for transformations (logarithm, square root, or square) that linearize the relation or change the distributional characteristics of data resulting in model residuals that are more symmetric, linear, and homoscedastic. To further evaluate potential models, diagnostic plots were created to assess how each model's residuals varied as a function of (1) predicted values, (2) normal quantiles, (3) date, and (4) streamflow. Additional plots highlight differences among predicted and observed values, residuals by season, and residuals by year. When comparing models with similar diagnostics, simple linear models, which are those with only one explanatory variable, are given preference to models with two explanatory variables.

The optimal model commonly used a transformed response variable. In those instances, a smearing estimator was used to correct for bias in the back transform of the model (Helsel and Hirsch, 2002). Prediction intervals were developed for each model, following methods from Helsel and Hirsch (2002), to define the range of values within which there is 90 -percent certainty that the true value occurs.

Once published, regression models can be used to estimate concentrations and loads of suspended sediment, total nitrogen, and total phosphorus. Daily loads of each constituent are computed as the product of daily mean model concentration, daily streamflow, and a conversion constant. Annual yields, in tons per square mile per year, are computed by dividing annual load, in tons, by the drainage area.

\section{Development and Use of Rloadest Models}

The rloadest program was used to develop secondary models for the computation of suspended-sediment load (SSL), total nitrogen load (TNL), and total phosphorus load
(TPL). LOADEST, a FORTRAN program originally developed by Runkel and others (2004), was updated by Runkel and De Cicco (2017) in the R programming language (R Core Team, 2018). The $\mathrm{R}$ version, called rloadest, is available on the USGS-R GitHub (https://github.com/USGS-R/rloadest). Models are typically developed in rloadest by regressing discrete concentration values (for suspended sediment, total nitrogen, or total phosphorus in this study) against concurrent daily mean streamflow values.

For each load model, the rloadest program computes regression coefficients by means of the adjusted maximum likelihood estimation method (Wolynetz, 1979). For each constituent, nine predefined models (Runkel and others, 2004) were tested, and the models were ranked based on Akaike information criterion (Helsel and Hirsch, 2002) scores.

After evaluating models based on the Akaike information criterion scores, diagnostic plots were created to assess the variance (as a function of predicted values and time) and normality of each model's residuals. Additionally, the rloadest program computes bias diagnostics that compare estimated loads to observed loads. Bias diagnostics for loads include the load bias percentage ( $B p$; the percentage by which the model overestimates [negative number] or underestimates [positive number] the sum of the estimated loads compared with the sum of the observed loads) and the partial load ratio (PLR; a ratio of the sum of the estimated loads to the sum of the observed loads, which indicates load overestimate [greater than 1] or underestimate [less than 1]). The Nash Sutcliffe efficiency index $(E)$ is computed by rloadest and provides a measure of model fit that ranges from 1 (perfect fit) to negative infinity. These diagnostics were used when selecting the model for each constituent.

After models were developed, daily mean discharge was used to estimate daily and monthly loads. For days when daily mean discharge was not available, the program waterData (Ryberg and Vecchia, 2012) mathematically assigned estimated streamflow for missing values. During this study, one missing daily mean discharge value ( 0.08 percent of the data), on October 25, 2016, was identified and estimated using waterData. To define parameter uncertainty and model error in the load estimations, 90-percent prediction intervals were computed for each model using the adjusted maximum likelihood estimation method (Cohn, 2005). Retransformation bias was automatically corrected by application of a bias correction factor (Bradu and Mundlak, 1970; Cohn, 1988, 2005).

\section{Results of Data Collection-Discrete and Continuous Water-Quality Data}

During the study period, discrete and continuous waterquality data were collected to describe instream conditions at the Iroquois River near Foresman, Ind. Discrete water-quality samples were manually collected at the continuous waterquality monitoring station and then analyzed at a laboratory. 
Discrete water-quality samples describe the instantaneous abundance of instream constituents. In situ water-quality monitors record continuous data every 15 minutes that represent river conditions during events, river extremes, and periods that field personnel are not at the site.

\section{Discrete Data}

During the study period, discrete concentration samples were collected throughout the range of hydrologic and seasonal conditions to represent each constituent's concentration at the Iroquois River near Foresman, Ind. Respectively, 30, 33 , and 34 water samples were collected, analyzed, and used in the development of suspended-sediment, total nitrogen, and total phosphorus regression models (table 1). No censored data (values below detection) were identified in this study.

Quality-control data were collected throughout the study to assess sampling variability and the potential for bias in the discrete sample results. Field blanks and replicate samples were collected each year and account for 10 percent of all samples collected. Field blanks help to identify potential contamination that may be introduced in the collection process. The contamination may be caused from inadvertent contact with equipment or may be introduced during analysis. Field blanks resulted in few detections above the laboratory reporting limit, and all detections were at least 80 percent below the median of the environmental population. Replicate samples were collected to understand the variability associated with collecting environmental data and to ensure sample results are reproducible. All replicate samples analyzed for nutrients and suspended sediment were within 10 percent of corresponding environmental samples.

\section{Continuous Data}

Water-quality monitors were deployed to continuously measure instream water properties. Continuous in situ measurements are beneficial because they provide data that can be collected at night and during storms under conditions that can have major effects on concentrations and loads and during

Table 1. Water-quality constituent data from discrete samples collected by the U.S. Geological Survey at the Iroquois River near Foresman, Indiana, continuous water-quality monitoring station (U.S. Geological Survey station 05524500), April 2015 through July 2018, and used in model development.

[USGS, U.S. Geological Survey; $n$, sample size]

\begin{tabular}{|c|c|c|c|c|c|}
\hline $\begin{array}{l}\text { Water-quality constituent } \\
\text { (milligrams per liter) }\end{array}$ & $\begin{array}{c}\text { USGS } \\
\text { parameter } \\
\text { code }\end{array}$ & $n$ & Range & Median & Standard deviation \\
\hline \multicolumn{6}{|c|}{ Discrete water-quality sample concentrations } \\
\hline $\begin{array}{l}\text { Suspended-sediment } \\
\text { concentration }\end{array}$ & 80154 & 30 & 10 to 186 & 35 & 42.11 \\
\hline $\begin{array}{l}\text { Nitrogen, water, unfiltered, } \\
\text { total as nitrogen }\end{array}$ & 62855 & 33 & 1.65 to 14.4 & 6.35 & 3.18 \\
\hline $\begin{array}{l}\text { Phosphorus, water, unfiltered, } \\
\text { total as phosphorus }\end{array}$ & 00665 & 34 & 0.041 to 0.547 & 0.128 & 0.13 \\
\hline
\end{tabular}

Table 2. Range of in situ, continuous streamflow and water-quality values measured at the Iroquois River near Foresman, Indiana, continuous water-quality monitoring station (U.S. Geological Survey station 05524500), March 2015 through July 2018.

[USGS, U.S. Geological Survey]

\begin{tabular}{lccc}
\hline \multicolumn{1}{c}{ Physical property or constituent } & $\begin{array}{c}\text { USGS } \\
\text { parameter code }\end{array}$ & $\begin{array}{c}\text { Range, during discrete } \\
\text { sample collection }\end{array}$ & Range, continuous data \\
\hline $\begin{array}{l}\text { Streamflow, in cubic feet per second } \\
\text { Water temperature, in degrees Celsius }\end{array}$ & 00060 & 79 to 5,030 & 40 to 5,270 \\
$\begin{array}{l}\text { Specific conductance, in microsiemens per } \\
\text { centimeter at 25 degrees Celsius }\end{array}$ & 00010 & 1.6 to 27.4 & -0.1 to 29.8 \\
pH, in standard units & 00095 & 177 to 739 & 171 to 845 \\
$\begin{array}{l}\text { Dissolved oxygen, in milligrams per liter } \\
\text { Turbidity, in formazin nephelometric units }\end{array}$ & 00400 & 7.1 to 8.2 & 6.9 to 8.4 \\
Nitrate plus nitrite, in milligrams per liter & 63680 & 3.5 to 12.9 & 2.7 to 16.2 \\
$\quad$ as nitrogen & 99133 & 1.06 to 12.2 & 0.0 to 600 \\
\hline
\end{tabular}


times when personnel may not be present to collect discrete samples. In this study, continuous water-quality data were used to provide a rich dataset for developing models. The models can be used to transform a discrete number of waterquality samples into thousands of virtual samples, substantially expanding the range of observed water-quality concentrations (table 2).

Minimally twice per year, an additional monitor was used to measure stream properties (water temperature, specific conductance, $\mathrm{pH}$, dissolved oxygen, and turbidity) across the sampling transect to verify that the in situ monitor location was representative of the average water-quality conditions (Wagner and others, 2006). Field results from 2015 to 2018 at the Iroquois River near Foresman, Ind., indicated that the continuous water-quality monitoring location was representative of the cross section and that the river was generally well mixed.

In situ measurements of nutrients by optical units in this study were not conducive for use in cross-section stream measurements. To assess instrument placement within the river, continuous, in situ nitrate plus nitrite measurements were compared to depth- and width-integrated discrete sample data collected during site visits (Lathrop, 2019b). Additionally, following USGS protocols, continuous data were checked for bias to determine if the in situ monitor overestimates or underestimates instream constituents (Pellerin and others, 2013). Continuous nutrient data collected in this study were representative of the cross section and were not systematically biased.

\section{Regression Models}

Peer-reviewed and approved discrete and continuous water-quality data were analyzed using ordinary least-squares regression techniques to develop "surrogate" regression models. The models were used to estimate concentrations and loads of suspended sediment, total nitrogen, and total phosphorus as a function of selected continuously measured parameters.

Several linear and multiple linear regression models were evaluated before selection of the best-fit models to estimate concentrations of suspended sediment, total nitrogen, and total phosphorus. Selected regression models used to compute each constituent are listed in table 3. Indepth model archive summaries are available for each constituent in companion USGS data releases (Lathrop, 2019a, b).

\section{Suspended-Sediment Concentration}

The best-fit suspended-sediment linear regression model used transformed variables to compute the suspendedsediment concentration $\left(\log _{10} S S C\right)$ from continuous turbidity $\left(\log _{10} T U R B\right)$ and streamflow (sqrt $Q$ ) and demonstrated the best overall model diagnostics (table 3 ). The root mean square error (0.123), which is a measure of the accuracy of predictions made with the regression line, is low compared to other models. The adjusted $R^{2}(0.84)$ indicated that the model

Table 3. Regression models for selected water-quality constituents at the Iroquois River near Foresman, Indiana, continuous water-quality monitoring station (U.S. Geological Survey station 05524500), March 2015 through July 2018.

[ $n$, sample size; RMSE, root mean square error; $R^{2}$, coefficient of determination; PRESS, predicted residual error sum of squares; log, logarithm; SSC, suspended-sediment concentration; TURB, turbidity, in formazin nephelometric units; sqrt, square root; $Q$, streamflow, in cubic feet per second; $T N$, total nitrogen; $N O_{x}$, nitrate plus nitrite, in milligrams per liter; $T P$, total phosphorus; $S C$, specific conductance, in microsiemens per centimeter at 25 degrees Celsius]

\begin{tabular}{|c|c|c|c|c|c|c|}
\hline Constituent & Equation & $\begin{array}{c}\text { Range of } \\
\text { variable values } \\
\text { used in model }\end{array}$ & $n$ & $\begin{array}{c}\text { RMSE } \\
\text { (constituent } \\
\text { units) }\end{array}$ & $\begin{array}{l}\text { Adjusted } \\
\qquad R^{2}\end{array}$ & $\begin{array}{l}\text { PRESS } \\
\text { statistic }\end{array}$ \\
\hline \multicolumn{7}{|c|}{ Iroquois River near Foresman, Indiana, regression models } \\
\hline $\begin{array}{l}\text { Suspended-sediment } \\
\text { concentration, } \\
\text { in milligrams per liter }\end{array}$ & $\begin{array}{l}\log _{10} S S C=0.64717+(0.81073 * \\
\left.\log _{10} T U R B\right)+(-0.0061 * \text { sqrt } Q)\end{array}$ & $\begin{array}{l}S S C=10 \text { to } 186 \\
T U R B=5.7 \text { to } 205 \\
Q=97 \text { to } 5,030\end{array}$ & 30 & 0.123 & 0.84 & 0.493 \\
\hline $\begin{array}{l}\text { Total nitrogen, water, } \\
\text { unfiltered, total as } \\
\text { nitrogen, in milligrams } \\
\text { per liter }\end{array}$ & $\begin{array}{c}\log _{10} T N=\left(0.8344 * \log _{10} N O_{x}\right)+ \\
\left(0.0382 * \log _{10} Q\right)+0.0962\end{array}$ & $\begin{array}{l}T N=1.65 \text { to } 14.40 \\
N O_{x}=1.06 \text { to } 12.20 \\
Q=79 \text { to } 5,030\end{array}$ & 33 & 0.0237 & 0.99 & 0.0202 \\
\hline $\begin{array}{l}\text { Total phosphorus, water, } \\
\text { unfiltered, total as } \\
\text { phosphorus, in } \\
\text { milligrams per liter }\end{array}$ & $\begin{array}{l}T P=\left(-0.34309 * \log _{10} S C\right)+ \\
\quad(0.03073 * \text { sqrtTURB })+0.96669\end{array}$ & $\begin{array}{l}T P=0.041 \text { to } 0.547 \\
S C=177 \text { to } 739 \\
T U R B=3.1 \text { to } 205\end{array}$ & 34 & 0.0513 & 0.84 & 0.0935 \\
\hline
\end{tabular}


predicts a large part of the variance in the suspended-sediment concentration dataset. The PRESS statistic (0.493) is improved with the multiple linear regression model (table 3 ).

The explanatory variables used to compute suspendedsediment concentration are logical statistically and physically. Suspended sediment positively correlates with in situ turbidity at the Iroquois River near Foresman, Ind. As the concentration of solids within the water column increases, the clarity of water commonly decreases. The movement of sediment within a river fluctuates with changing streamflow. Typically, the largest movement of sediment as caused by a streamflow event occurs on the rising limb of the streamflow hydrograph, followed by a decrease in sediment transport during extended periods of high streamflow and during declining streamflow. As such, streamflow alone is not a good predictor of suspended-sediment concentrations but can be used to explain some variability in a multiple linear regression model.

Additional transformations and explanatory variables were evaluated to compute suspended-sediment concentration. Specific conductance was significant in multiple linear regression models that used turbidity as an explanatory variable, but the models resulted in nonsymmetrical residuals. Exploratory statistics indicated that transformed turbidity ( $\operatorname{sqrtTURB})$ in a simple linear regression model might be used to compute suspended-sediment concentration, but diagnostic plots of model residuals as a function of time and streamflow were improved when streamflow was added as an additional explanatory variable (Lathrop, 2019a).

\section{Total Nitrogen}

The best-fit total nitrogen linear regression model uses transformed variables to compute total nitrogen $\left(\log _{10} T N\right)$ from continuous nitrate plus nitrite $\left(\log _{10} N O_{x}\right)$ and streamflow $\left(\log _{10} Q\right)$ (table 3$)$. The model has a low root mean square error (0.0237), a high adjusted $R^{2}(0.99)$, and a low PRESS statistic (0.0202; table 3$)$. Model residuals graphed by season and year are improved from simple linear regression models. Comparison of measured total nitrogen values to computed values indicates that the model provides a good fit to the measured dataset.

The explanatory variables used to compute total nitrogen are logical statistically and physically. Continuous measurement of nitrate plus nitrite is appropriate as an explanatory variable because of the large composition of total nitrogen from nitrate and nitrite ( 82 percent) measured in discrete samples at the Iroquois River near Foresman, Ind. Rises in streamflow from rainfall and runoff may increase the total nitrogen concentration in the stream because of the entrainment and transport of nitrogen from nonpoint sources. Conversely, rising streamflow may lead to dilution of nitrogen entering the stream from point sources. Streamflow levels also may be indicative of the relative contributions of groundwater, shallow subsurface flow, surface runoff, and subsurface drainage, each of which may contribute higher or lower amounts of nutrients.

Initially, exploratory statistics indicated that untransformed total nitrogen could be computed directly from continuous nitrate and nitrite. Further review of model residuals as a function of time and streamflow indicated that an additional variable(s) or transformation(s), or both, might help linearize the relation. The addition of streamflow to the model and the transformation of each of the variables improved the distributional characteristics of the data and resulted in model residuals that were more normally distributed.

\section{Total Phosphorus}

The best-fit total phosphorus model computes untransformed total phosphorus from the transformed explanatory variables specific conductance $\left(\log _{10} S C\right)$ and turbidity (sqrtTURB) and demonstrates the best overall model diagnostics (table 3$)$. The root mean square error $(0.0513)$ is low and provides confidence regarding the accuracy of predictions made with the regression line. The adjusted $R^{2}(0.84)$ indicates the model does a good job of predicting the variance in the total phosphorus dataset. The PRESS statistic (0.0935), calculated in the leave-one-out cross-validation process, indicates good model fit (table 3).

The use of turbidity and specific conductance as explanatory variables is appropriate physically and statistically. In rivers, soluble phosphorus or orthophosphate commonly binds to sediment, whereas particulate phosphorus is commonly transported because of erosion (Mueller and Helsel, 1996). As a result, increased turbidity typically coincides with increased concentrations of total phosphorus within the river (Lathrop, 2019b). Because specific conductance typically inversely correlates with streamflow, continuous specific conductance was used to represent changes in flow regimes within the model, while also acting as a measure of dissolved orthophosphate. During this study, orthophosphate accounted for a large part of total phosphorus (46 percent) in discrete samples (U.S. Geological Survey, 2016b). Continuous and discrete data analysis indicated that high streamflow-low specific conductance events correlated with elevated total phosphorus concentrations, whereas lower total phosphorous concentrations were determined in samples during low streamflow-high specific conductance periods (Lathrop, 2019b). Continuous specific conductance also may reflect the predominate sources of water at different flows; for example, groundwater, shallow subsurface flow, surface runoff, and subsurface drainage (Stewart and others, 2007; Sanford and others, 2012; Miller and others, 2014, 2016). Finally, differences in flow contribution from different subbasins may be represented by specific conductance.

The selected model does the best job of computing total phosphorus over the range of specific conductance, turbidity, and streamflow. Additional variables were evaluated to better define differences in seasonality. Unfortunately, because of the limitations on the number of explanatory variables that may be 
used in a model with 34 samples, variables that better define seasonality could not be included. Ultimately, models that decreased residual size by improving seasonality computation resulted in larger residuals during high-flow conditions.

\section{Constituent Load Models}

At the Iroquois River near Foresman, Ind., daily loads of suspended sediment, total nitrogen, and total phosphorus were computed for April 2015 through July 2018 as the product of regression model daily mean concentrations and daily mean streamflow. During periods when regression model concentrations were not available, rloadest models were used to compute daily loads of each constituent.

\section{Rloadest Model Results}

For the Iroquois River near Foresman, Ind., rloadest was used to compute secondary load models of suspended sediment, total nitrogen, and total phosphorus from daily mean streamflow. In rloadest, model 1 (of the nine predefined models in Runkel and others [2004]), which uses the natural logarithm of daily mean streamflow minus the natural logarithm of the centered value of daily mean streamflow from the calibration dataset $(\ln [Q])$ as the predictive variable, was selected as the model for suspended sediment $\left(R^{2}=0.78\right.$, probability $[p$-value] less than $[<] 0.0001, B p=-5.354, P L R=$ $0.9465, E=0.425$; Bunch, 2019). Model 2 (Runkel and others, 2004), which uses the variables, $\ln (Q)$ and $\ln (Q)^{2}$, was selected as the model for total phosphorus $\left(R^{2}=0.89, p\right.$-value $<0.0001$, $B p=9.784, P L R=1.098, E=0.6924)$ and total nitrogen $\left(R^{2}=\right.$ $0.96, p$-value $<0.0001, B p=0.4194, P L R=1.004, E=0.8644$; Bunch, 2019). Residual plots and further supporting information on model development are available in a USGS data release (Bunch, 2019).

\section{Load Estimation Computations for Suspended Sediment, Total Nitrogen, and Total Phosphorus}

Loads of suspended sediment, total nitrogen, and total phosphorus were computed for the Iroquois River near Foresman, Ind., from April 2015 through July 2018. Daily loads were the product of regression model daily mean concentrations and daily mean streamflow. Regression model loads were not computed when continuous explanatory variables (1) exceeded USGS fouling or drift thresholds and required deletion, (2) were not recorded because of in situ instrument failure or removal, or (3) were 10 percent greater than the range of the regression model calibration dataset and exceeded USGS guidelines (U.S. Geological Survey, 2016c). During periods that regression model concentrations could not be used, daily loads were computed from the rloadest models for suspended sediment (20 percent of the study period), total nitrogen (11 percent of the study period), and total phosphorus (20 percent of study period).

Monthly and annual loads of suspended sediment, total nitrogen, and total phosphorus were computed by combining regression (primary) and rloadest (secondary) model daily loads (fig. 2, table 4, respectively). To evaluate the uncertainty of estimated loads, 90-percent prediction intervals of the monthly loads were developed by combining the error from the regression and rloadest models in the proportion each was used. Prediction intervals of the combined load models were larger during periods when rloadest was used to compute a greater proportion of constituent loads.

\section{Suspended-Sediment Load}

The total SSL for the Iroquois River near Foresman, Ind., from April 2015 through July 2018 was estimated at 101,000 tons (table 4). The 2015 partial year SSL (April through December 2015) was 24,000 tons. The annual SSL for 2016 and 2017 was 25,000 and 32,100 tons, respectively. The 2018 partial year SSL (January through July 2018) was 19,900 tons. Estimated monthly SSL ranged from 170 (October 2015) to 9,180 (February 2018) tons per month with a median SSL of 1,840 tons per month (fig. 2B). Annual suspended-sediment yields for 2016 and 2017 were 55.4 and 71.5 tons per square mile per year $\left(\mathrm{t} / \mathrm{mi}^{2} / \mathrm{yr}\right)$, respectively (table 4).

\section{Total Nitrogen Load}

The TNL for the Iroquois River near Foresman, Ind., from April 2015 through July 2018 was estimated at 17,400 tons (table 4). The 2015 partial year TNL (April through December 2015) was 4,370 tons. The annual TNL for 2016 and 2017 was 4,260 and 5,780 tons, respectively. The 2018 partial year TNL (January through July 2018) was 2,960 tons. Estimated monthly TNL ranged from 11.9 (October 2015) to 2,090 (June 2015) tons per month with a median TNL of 411 tons per month (fig. $2 C$ ). The annual total nitrogen yields for 2016 and 2017 were approximately 9.5 and $12.8 \mathrm{t} / \mathrm{mi}^{2} / \mathrm{yr}$, respectively (table 4 ).

\section{Total Phosphorus Load}

The TPL for the Iroquois River near Foresman, Ind., from April 2015 through July 2018 was estimated at 478 tons (table 4). The 2015 partial year TPL (April through December 2015) was 148 tons. The annual TPL for 2016 and 2017 was 104 and 128 tons, respectively. The 2018 partial year TPL (January through July 2018) was 98.2 tons. Estimated monthly TPL ranged from 0.835 (October 2015) to 63.9 (June 2015) tons per month with a median TPL of 7.91 tons per month (fig. 2D). The annual total phosphorus yields for 2016 and 2017 were 0.23 and $0.28 \mathrm{t} / \mathrm{mi}^{2} / \mathrm{yr}$, respectively. 

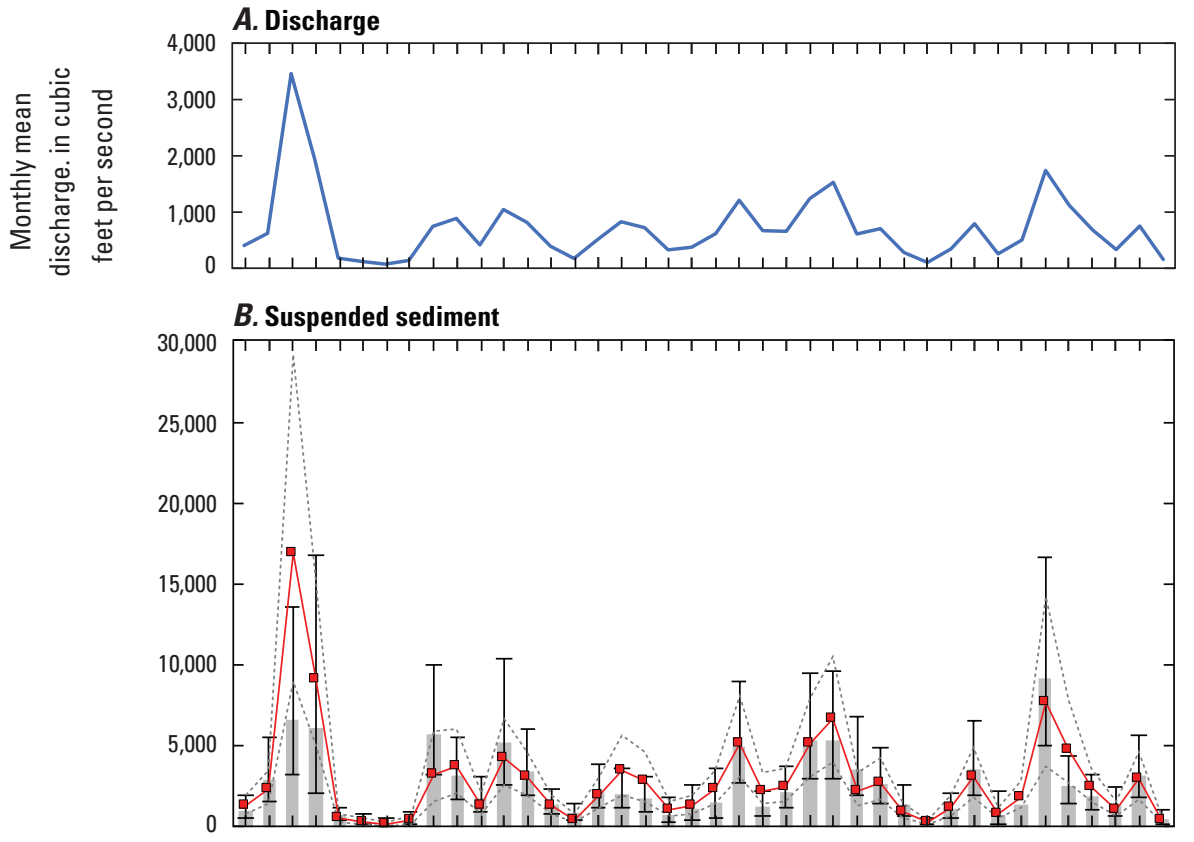

C. Total nitrogen
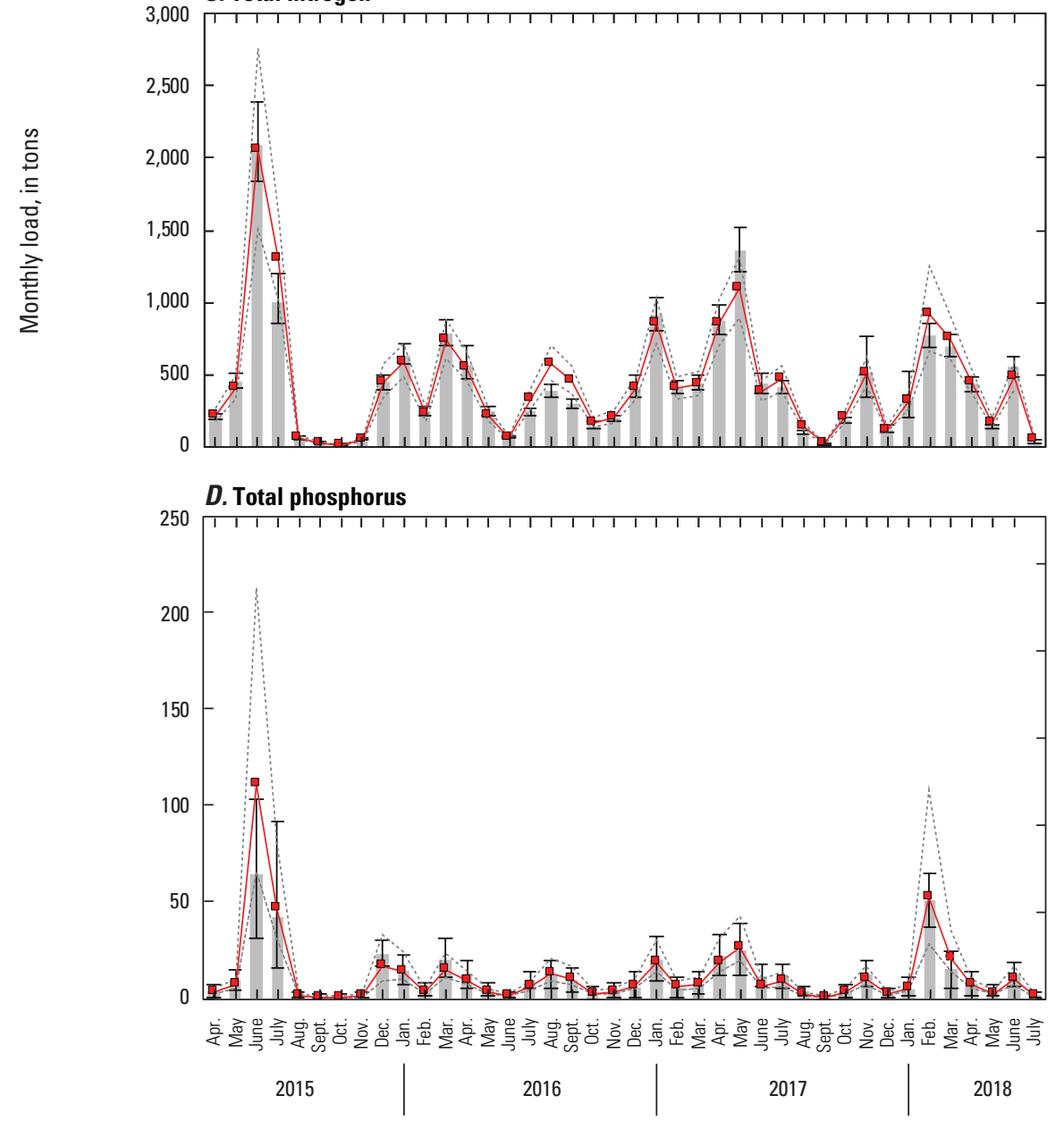

\section{EXPLANATION}

I Load estimate from regression model with missing days estimated by rloadest and 90 -percent prediction interval

Monthly mean discharge

Rloadest 90-percent prediction interval

$\longrightarrow \quad$ Load estimate from rloadest model 
Table 4. Estimated annual loads and yields of suspended sediment, total nitrogen, and total phosphorus computed from daily loads of regression and rloadest models for the Iroquois River near Foresman, Indiana, continuous water-quality monitoring station (U.S. Geological Survey station 05524500), from April 2015 through July 2018.

[--, no data; N, nitrogen; P, phosphorus $]$

\begin{tabular}{|c|c|c|c|c|}
\hline Period & $\begin{array}{l}\text { Load } \\
\text { (tons) }\end{array}$ & $\begin{array}{c}\text { Load (tons), 90-percent } \\
\text { prediction interval }\end{array}$ & $\begin{array}{c}\text { Yield } \\
\text { (tons/square mile/year) }\end{array}$ & $\begin{array}{l}\text { Days estimated by } \\
\text { rloadest models }\end{array}$ \\
\hline \multicolumn{5}{|c|}{ Suspended sediment } \\
\hline $4 / 1 / 2015-12 / 31 / 2015$ & 24,000 & 11,400 to 51,400 & -- & 87 \\
\hline $1 / 1 / 2016-12 / 31 / 2016$ & 25,000 & 13,100 to 47,700 & 55.4 & 58 \\
\hline $1 / 1 / 2017-12 / 31 / 2017$ & 32,100 & 17,400 to 59,700 & 71.5 & 55 \\
\hline $1 / 1 / 2018-7 / 31 / 2018$ & 19,900 & 10,900 to 36,800 & -- & 41 \\
\hline Total & 101,000 & 52,800 to 196,000 & -- & 241 \\
\hline \multicolumn{5}{|c|}{ Total nitrogen, as $\mathrm{N}$} \\
\hline $4 / 1 / 2015-12 / 31 / 2015$ & 4,370 & 3,830 to 5,020 & -- & 58 \\
\hline $1 / 1 / 2016-12 / 31 / 2016$ & 4,260 & 3,750 to 4,880 & 9.5 & 13 \\
\hline $1 / 1 / 2017-12 / 31 / 2017$ & 5,780 & 5,020 to 6,720 & 12.8 & 36 \\
\hline $1 / 1 / 2018-7 / 31 / 2018$ & 2,960 & 2,520 to 3,440 & -- & 33 \\
\hline Total & 17,400 & 15,100 to 20,100 & -- & 140 \\
\hline \multicolumn{5}{|c|}{ Total phosphorus, as $\mathrm{P}$} \\
\hline $4 / 1 / 2015-12 / 31 / 2015$ & 148 & 70.2 to 260 & -- & 90 \\
\hline $1 / 1 / 2016-12 / 31 / 2016$ & 104 & 45.6 to 171 & 0.23 & 60 \\
\hline $1 / 1 / 2017-12 / 31 / 2017$ & 128 & 58.9 to 205 & 0.28 & 59 \\
\hline 1/1/2018-7/31/2018 & 98.2 & 55.0 to 144 & -- & 41 \\
\hline Total & 478 & 230 to 780 & -- & 250 \\
\hline
\end{tabular}

\section{Limitations}

Discrete and continuous water-quality data collected at the Iroquois River near Foresman, Ind., were collected throughout the range of hydrologic and seasonal conditions and are assumed to be independent observations. Samples that are collected too closely in time may be serially correlated, which is the correlation of a signal with a delayed copy of itself as a function of delay (Helsel and Hirsch, 2002). For example, on rivers, the rise or fall in streamflow or a waterquality concentration caused by an event may be 1 week or more, which could be a source for serial correlation within the data for samples collected weekly. Serial correlation among residuals can bias model diagnostics that assume independent observations (for example, PRESS and prediction interval). The sampling frequency at the Iroquois River near Foresman, Ind., was every 2 weeks or longer to eliminate potential serial correlation.

The regression models published in this report (table 3) were computed based on concurrent continuous and discrete water-quality measurements at the Iroquois River near Foresman, Ind. Although site visits were scheduled to cover the range of seasonal conditions and were later adjusted to capture observed peaks in water-quality properties, the complete range of in situ continuous measurements cannot be represented by discrete samples. Extrapolation, which is the use of regression models outside the range of the model calibration data, should be restricted to no more than 10 percent of the maximum or minimum continuous value(s) used in the development of each model (table 2).

The rloadest models were calibrated with discrete concentration data and daily mean streamflow. When explanatory variables exceeded the range of the calibration dataset, the regression equations were extrapolated, which may result in larger error associated with load estimates, less confidence, and wider prediction intervals.

\section{Summary}

The Iroquois River drains 660 square miles of area in northwestern Indiana. Extensive anthropogenic changes to the river began in the late 19th century, altering the basin for improved agricultural use and resulting in increased transport of sediment and nutrients to downstream rivers. In 2015, in cooperation with the Iroquois River Conservancy District, the Iroquois River near Foresman, Indiana, streamflow-gaging station (U.S. Geological Survey station 05524500) was upgraded 
to provide real-time estimates of concentrations and loads of suspended sediment, total nitrogen, and total phosphorus. Site-specific models developed using linear regression relate continuous data and discrete water-quality samples collected from April 2015 through July 2018. Regression models indicated strong correlations between turbidity and streamflow with suspended-sediment concentration (adjusted coefficient of determination $\left[R^{2}\right]=0.84$, predicted residual error sum of squares $[\mathrm{PRESS}]=0.493$ ), nitrate plus nitrite and streamflow with total nitrogen (adjusted $R^{2}=0.99$, PRESS $=0.0202$ ), and specific conductance and turbidity with total phosphorus (adjusted $R^{2}=0.84$, PRESS $=0.0935$ ).

Daily loads of suspended sediment, total nitrogen, and total phosphorus were computed as the product of daily mean regression model concentrations and daily mean streamflow. During periods when explanatory variables exceeded quality thresholds, were not recorded, or were greater than 10 percent of the calibration dataset, regression model loads could not be computed and rloadest computed loads were used. For 2016 and 2017, the estimated annual suspended-sediment loads were 25,000 and 32,100 tons; estimated annual total nitrogen loads were 4,260 and 5,780 tons; and estimated annual total phosphorus loads were 104 and 128 tons, respectively. The development of regression models to compute concentrations and loads of suspended sediment, total nitrogen, and total phosphorous provides a tool for resource managers and the public to quantify constituent transport and assess any effects that environmental factors changing land use practices, and management decisions have upon the Iroquois River.

\section{References Cited}

Bhowmik, N.G., Bonini, A.P., Bogner, W.C., and Byrne, R.P., 1980, Hydraulics of flow and sediment transport in the Kankakee River in Illinois: Champaign, Ill., Illinois State Water Survey Report of Investigation 98, 170 p., accessed August 15, 2018, at https://www.ideals. illinois.edu/bitstream/handle/2142/77770/ISWSRI-98. pdf? sequence $=2$ \&isAllowed $=\mathrm{y}$.

Bradu, D., and Mundlak, Y., 1970, Estimation in lognormal linear models: Journal of the American Statistical Association, v. 65, no. 329, p. 198-211.

Bunch, A.R., 2019, Suspended sediment, total nitrogen, and total phosphorus loads for Iroquois River near Foresman, Indiana, April 2015 to July 2018: U.S. Geological Survey data release, https://doi.org/10.5066/P91FL2GY.

Cohn, T.A., 1988, Adjusted maximum likelihood estimation of the moments of lognormal populations from type 1 censored samples: U.S. Geological Survey Open-File Report 88-350, 34 p. [Also available at https://doi.org/10.3133/ofr88350.]
Cohn, T.A., 2005, Estimating contaminant loads in rivers-An application of adjusted maximum likelihood to type 1 censored data: Water Resources Research, v. 41, no. 7. [Also available at https://doi.org/10.1029/2004WR003833.]

Demissie, M., Bhowmik, N.G., and Adams, J.R., 1983, Hydrology, hydraulics, and sediment transport, Kankakee and Iroquois Rivers: Champaign, Ill., Illinois State Water Survey Report of Investigation 103, 66 p., accessed April 14, 2019, at https://www.ideals.illinois.edu/bitstream/handle/2142/77806/ISWSRI-103. pdf? sequence $=2$ \&isAllowed $=y$.

Fishman, M.J., ed., 1993, Methods of analysis by the U.S. Geological Survey National Water Quality LaboratoryDetermination of inorganic and organic constituents in water and fluvial sediments: U.S. Geological Survey OpenFile Report 93-125, 217 p. [Also available from https://doi. org/10.3133/ofr93125.]

Gray, H.H., 2001, Map of Indiana showing physiographic divisions: Indiana Geological Survey Miscellaneous Map 69, scale 1:1,624,615, accessed April 14, 2019, at https:// igws.indiana.edu/ReferenceDocs/Maps/PhysiographicRegions.pdf.

Guy, H.P., 1969, Laboratory theory and methods for sediment analysis: U.S. Geological Survey, Techniques of Water-Resources Investigations, book 5, chap. C1, 58 p. [Also available at https://pubs.usgs.gov/twri/twri5c1/pdf/ TWRI_5-C1.pdf.]

Helsel, D.R., and Hirsch, R.M., 2002, Statistical methods in water resources: U.S. Geological Survey Techniques of Water-Resources Investigations, book 4, chap. A3, 522 p. [Also available at https://pubs.usgs.gov/twri/twri4a3/.]

Holmes, R.R., Jr., 1997, Suspended-sediment budget for the Kankakee River Basin, 1993-95: U.S. Geological Survey Open-File Report 97-120, 8 p. [Also available at https:// pubs.er.usgs.gov/publication/ofr97120.]

Homoya, M.A., Abrell, D.B., Aldrich, J.R., and Post, T.W., 1985, The natural regions of Indiana: Indiana Academy of Science, v. 94, p. 245-268, accessed April 14, 2019, at https://www.in.gov/dnr/naturepreserve/files/np-npHomoya_Aldrich_Abrell_Post_doc.pdf.

Indiana Geological Survey, 2019, IndianaMAP: Indiana Geological Survey, scale variable, accessed April 14, 2019, at https://maps.indiana.edu/.

Ivens, J.L., Bhowmik, N.G., Brigham, A.R., and Gross, D.L., 1981, The Kankakee River-Yesterday and today: Illinois Department of Energy and Natural Resources, Illinois State Water Survey Miscellaneous Publication 60, 24 p., accessed April 14, 2019, at https://www.isws.illinois.edu/pubdoc/MP/ ISWSMP-60.pdf. 
Jarvis, M., 2001, Iroquois River Watershed Restoration Action Strategy, part I-Characterization and responsibility: Indiana Department of Environmental Management, Office of Water Quality, 44 p., accessed April 15, 2019, at https:// www.in.gov/idem/nps/files/wras_iroquois_part1.pdf.

Jonas, M., and Little, C., 2010, SIAM case study-Kankakee River Basin, Indiana and Illinois: 2d Joint Federal Interagency Conference, Las Vegas, Nev., June 27-July 1, 2010, 12 p., accessed April 14, 2019, at https://acwi.gov/ sos/pubs/2ndJFIC/Contents/11C_Jonas_SIAM_Kankakee_ paper-jmbpdf.pdf.

Lathrop, T.R., 2019a, Data and regression model for suspended sediment for Iroquois River near Foresman, Indiana, March 20, 2015, to July 19, 2018: U.S. Geological Survey data release, https://doi.org/10.5066/P9RFLONI.

Lathrop, T.R., 2019b, Data and regression models for total nitrogen and total phosphorus for the Iroquois River near Foresman, Indiana, March 20, 2015, to July 19, 2018: U.S. Geological Survey data release https://doi.org/10.5066/ P9YCAELC.

Miller, M.P., Buto, S.G., Susong, D.D., and Rumsey, C.A., 2016, The importance of base flow in sustaining surface water flow in the Upper Colorado River Basin: Water Resources Research, v. 52, no. 5, p. 3547-3562. [Also available at https://doi.org/10.1002/2015WR017963].

Miller, M.P., Susong, D.D., Shope, C.L., Heilweil, V.H., and Stolp, B.J., 2014, Continuous estimation of baseflow in snowmelt-dominated streams and rivers in the Upper Colorado River Basin-A chemical hydrograph separation approach: Water Resources Research, v. 50, no. 8, p. 6986-6999. [Also available at https://doi. org/10.1002/2013WR014939.]

Mueller, D.K., and Helsel, D.R., 1996, Nutrients in the Nation's waters - Too much of a good thing?: U.S. Geological Survey Circular 1136, 24 p. [Also available at https:// pubs.usgs.gov/circ/1996/1136/report.pdf.]

O’Dell, J.W., ed., 1993, Method 365.1, revision 2.0-Determination of phosphorus by semi-automated colorimetry: U.S. Environmental Protection Agency, 18 p. [Also available at https:/www.epa.gov/sites/production/files/2015-08/documents/method_365-1_1993.pdf.]

Patton, C.J., and Kryskalla, J.R., 2003, Methods of analysis by the U.S. Geological Survey National Water Quality Laboratory_Evaluation of alkaline persulfate digestion as an alternative to Kjeldahl digestion for determination of total and dissolved nitrogen and phosphorus in water: U.S. Geological Survey Water-Resources Investigations Report 2003-4174, 33 p. [Also available at https://doi.org/10.3133/ wri034174.]
Patton, C.J., and Kryskalla, J.R., 2011, Colorimetric determination of nitrate plus nitrite in water by enzymatic reduction, automated discrete analyzer methods: U.S. Geological Survey Techniques and Methods, book 5, chap. B8, 34 p., [Also available at https://pubs.usgs.gov/tm/05b08/.]

Pellerin, B.A., Bergamaschi, B.A., Downing, B.D., Saraceno, J.F., Garrett, J.D., and Olsen, L.D., 2013, Optical techniques for the determination of nitrate in environmental watersGuidelines for instrument selection, operation, deployment, maintenance, quality assurance, and data reporting: U.S. Geological Survey Techniques and Methods, book 1, chap. D5, 37 p. [Also available at https://doi.org/10.3133/tm1D5.]

Perkins, D.M., 2013, Upper Iroquois River Watershed Management Plan: Upper Iroquois River Watershed Initiative, EDS no. A305-10-81, 258 p., accessed April 14, 2019, at https://www.in.gov/idem/nps/files/wmp_iroquois_riverupper_10-81.pdf.

Phipps, R.L., Johnson, G.P., and Terrio, P.J., 1995, Dendrogeomorphic estimate of changes in sedimentation rate along the Kankakee River near Momence, Illinois: U.S. Geological Survey Water-Resources Investigations Report 94-4190, 30 p. [Also available at https://pubs.er.usgs.gov/publication/ wri944190.]

R Core Team, 2018, R-A language and environment for statistical computing: Vienna, Austria, R Foundation for Statistical Computing, accessed September 12, 2018, at https://www.R-project.org/.

Rasmussen, P.P., Gray, J.R., Glysson, G.D., and Ziegler, A.C., 2009, Guidelines and procedures for computing time-series suspended-sediment concentrations and loads from instream turbidity-sensor and streamflow data: U.S. Geological Survey Techniques and Methods, book 3, chap. C4, $53 \mathrm{p}$.

Risch, M.R., Bunch, A.R., Vecchia, A.V., Martin, J.D., and Baker, N.T., 2014, Water quality in Indiana-Trends in concentrations of selected nutrients, metals, and ions in streams, 2000-10: U.S. Geological Survey Scientific Investigations Report 2014-5205, 47 p., accessed April 18, 2019, at http://dx.doi.org/10.3133/sir20145205.

Runkel, R.L., Crawford, C.G., and Cohn, T.A., 2004, Load estimator (LOADEST) —A FORTRAN program for estimating constituent loads in streams and rivers: U.S. Geological Survey Techniques and Methods, book 4, chap. A5, 69 p., accessed September 12, 2018, at https://doi. org/10.3133/tm4A5.

Runkel, R.L., and De Cicco, L.A., 2017, USGS water science $\mathrm{R}$ functions for LOAD ESTimation of constituents in rivers and streams: R package, version 0.4.5, accessed September 12, 2018, at https://github.com/USGS-R/rloadest. 
Ryberg, K.R., and Vecchia, A.V., 2012, waterData-An R package for retrieval, analysis, and anomaly calculation of daily hydrologic time series data, version 1.0: U.S. Geological Survey Open-File Report 2012-1168, 8 p., accessed September 12, 2018, at https://doi.org/10.3133/ ofr20121168.

Sanford, W.E., Nelms, D.L., Pope, J.P., and Selnick, D.L., 2012, Quantifying components of the hydrologic cycle in Virginia using chemical hydrograph separation and multiple regression analysis: U.S. Geological Survey Scientific Investigations Report 2011-5198, 78 p. [Also available at https://doi.org/10.3133/sir20115198.]

Smith, R.A., Alexander, R.B., and Schwarz, G.E., 2003, Natural background concentrations of nutrients in streams and rivers of the conterminous United States: Environmental Science \& Technology, v. 37, no. 14, p. 3039-3047, accessed April 14, 2019, at https:/water.usgs.gov/nawqa/ sparrow/intro/es\&t.pdf.

Stewart, M., Cimino, J., and Ross, M., 2007, Calibration of base flow separation methods with streamflow conductivity: Ground Water, v. 45, no. 1, p. 17-27. [Also available at https://doi.org/10.1111/j.1745-6584.2006.00263.x.]

Sullivan, D.J., 2000, Nutrients and suspended solids in surface waters of the Upper Illinois River Basin in Illinois, Indiana, and Wisconsin, 1978-97: U.S. Geological Survey WaterResources Investigations Report 99-4275, 57 p., accessed April 18, 2019, at https://pubs.usgs.gov/wri/1999/4275/ report.pdf.

Terrio, P.J., and Nazimek, J.E., 1997, Changes in crosssection geometry and channel volume in two reaches of the Kankakee River in Illinois, 1959-94: U.S. Geological Survey Water-Resources Investigations Report 96-4261, 41 p. [Also available at https://pubs.er.usgs.gov/publication/ wri964261.]

U.S. Geological Survey, variously dated, National field manual for the collection of water-quality data: U.S. Geological Survey Techniques of Water-Resources Investigations, book 9, chaps. A1-A10, accessed November 27, 2018, at https://pubs.water.usgs.gov/twri9A.

U.S. Geological Survey, 2016a, The StreamStats program: U.S. Geological Survey web page, accessed April 14, 2019, at https://water.usgs.gov/osw/streamstats/.

U.S. Geological Survey, 2016b, USGS water data for the Nation: U.S. Geological Survey National Water Information System database, accessed June 10, 2012, at https://doi. org/10.5066/F7P55KJN.

U.S. Geological Survey, 2016c, Office of Water Quality Technical Memorandum 2016.10: Reston, Va., U.S. Geological Survey, 40 p., accessed May 1, 2018, at https://water.usgs. gov/admin/memo/QW/qw2016.10.pdf.
Wagner, R.J., Boulger, R.W., Jr., Oblinger, C.J., and Smith, B.A., 2006, Guidelines and standard procedures for continuous water-quality monitors - Station operation, record computation, and data reporting, version 1.0: U.S. Geological Survey Techniques and Methods, book 1, chap. D3, 51 p., 8 attachments, accessed November 27, 2018, at https:// pubs.usgs.gov/tm/2006/tm1D3/.

Wolynetz, M.S., 1979, Algorithm AS 139-Maximum likelihood estimation in a linear model with confined and censored normal data: Applied Statistics, v. 28, no. 2, p. 195206. [Also available at https://doi.org/10.2307/2346749.]
For additional information, contact: Director, Ohio-Kentucky-Indiana Water Science Center U.S. Geological Survey

5957 Lakeside Boulevard

Indianapolis, IN 46278

317-290-3333

For additional information, visit: https://www.usgs.gov/centers/oki-water

Publishing support provided by the Rolla Publishing Service Center 



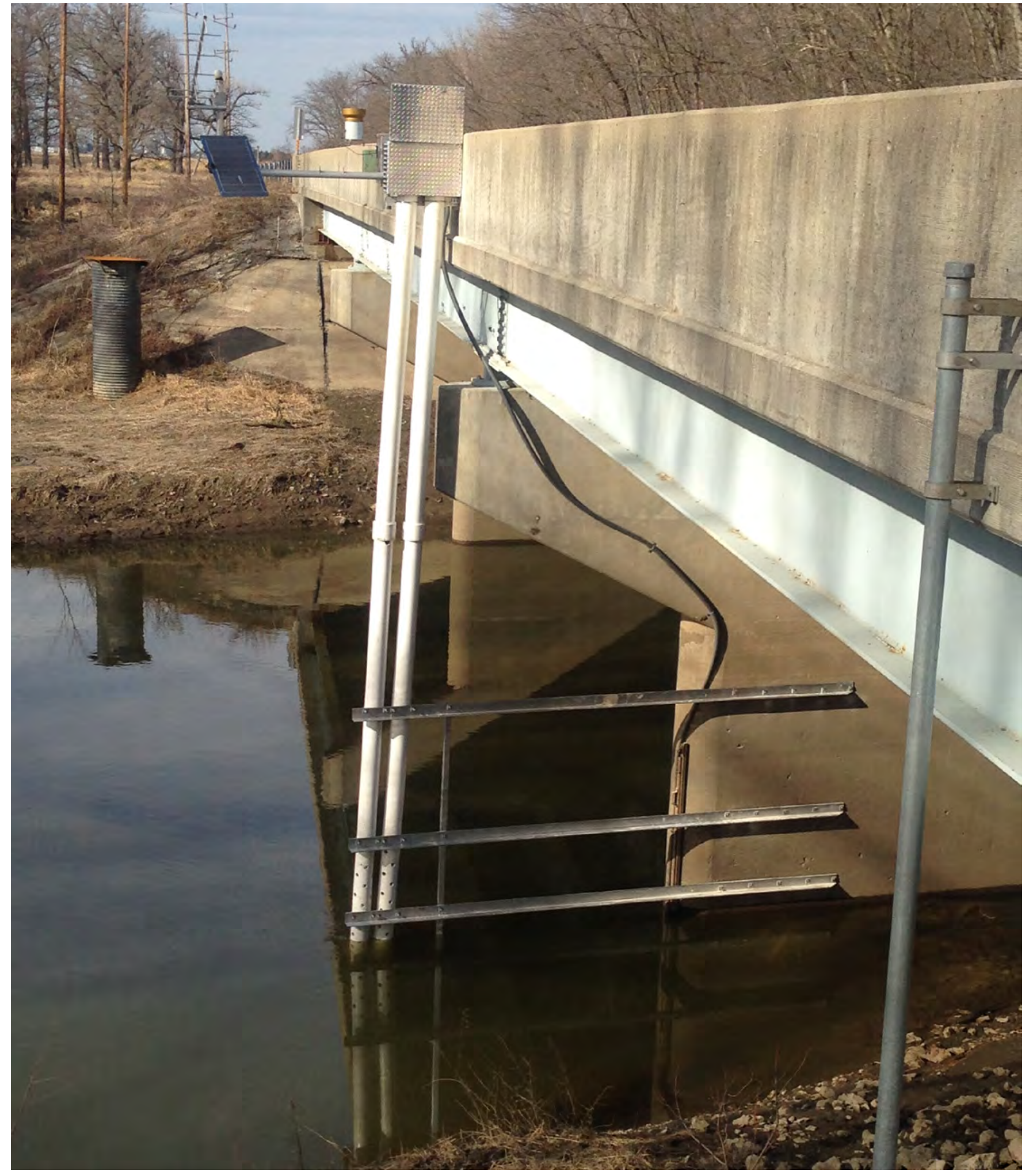

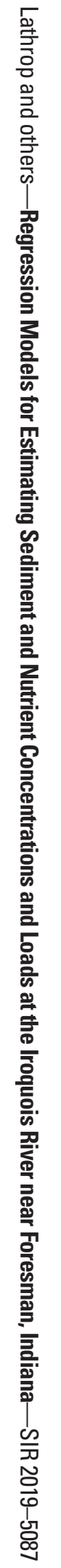

